\title{
PENERAPAN STANDAR GRI DALAM LAPORAN KEBERLANJUTAN DI INDONESIA: SEBUAH EVALUASI
}

\author{
Randy Kuswanto \\ Sekolah Tinggi Ilmu Ekonomi Wiyatamandala \\ randy.kuswanto@wiyatamandala.ac.id
}

\begin{abstract}
This study aims to investigate the level of conformity of economic, social, and environmental information on sustainability report in Indonesia as per GRI G4 guidelines. Content analysis has been applied to a sample of 29 companies listed in the Indonesia Stock Exchange. Conformity and disclosure quality were analyzed descriptively using a specific scoring system for each dimensions. The findings of this research show that the level of conformity of GRI indicators in Indonesia is quite low at 18,9\%. However, the weight of information disclosed by companies is relatively high, at 59,9\% of the information. This wide gap occurred caused by the fact that many companies disclose only a few indicators of GRI G4. These findings indicate the GRI G4 Guidelines is not really suitable for company in Indonesia. One of the primary focuses of this research is the applicability of GRI indicators. However, not even a single study found while reviewing literature that studied the applicability GRI indicators in a country. Conformity can become a new topic when studying accounting information disclosure.
\end{abstract}

Keywords: Global Reporting Initiative (GRI), Content Analysis, Sustainability Reporting, Social and Environmental Information

\section{PENDAHULUAN}

Sejak awal dekade 2000-an laporan keberlanjutan secara resmi mulai dipublikasikan oleh beberapa perusahaan di belahan dunia. Di Indonesia, tren ini dimulai sejak tahun 2006 saat PT Kaltim Prima Coal menerbitkan laporan keberlanjutan untuk pertama kalinya dengan menggunakan pedoman GRIG2. Laporan keberlanjutan (sustainability report) semakin populer dipublikasikan oleh perusahaan sebagai alat komunikasi perusahaan dalam mengungkapkan bagaimana kontribusi pembangunan keberlanjutan (Cantele et al. 2018; Tsalis et al 2018). Laporan keberlanjutan juga dijadikan sebagai alat untuk meraih legitimasi dari masyarakat selaku salah satu stakeholder (Ching dan Gerab, 2016; Murphy dan McGrath, 2013). Penggunaan pedoman GRI yang 
universal mampu membuat laporan keberlanjutan yang nantinya memiliki komparabilitas tinggi walaupun digunakan oleh banyak negara di dunia. Padahal terdapat indikasi bahwa indikator GRI tidak dapat diterapkan sepenuhnya dan tidak menghasilkan kualitas pelaporan yang informatif (Khan et al. 2011; Cuesta dan Valor 2013). Penelitian ini menguji keberterimaan informasi keberlanjutan di Indonesia. Belum ada penelitian yang menguji konformitas indikator GRI. Perusahaan mungkin mengalami kesulitan dalam memenuhi persyaratan indikator-indikator GRI. Bahkan, budaya dan peraturan di suatu negara dapat membuat indikator GRI memang benar-benar tidak dapat diterapkan di negara tersebut (Khan et al., 2011). Studi empiris dan teoritikal sebelumnya menunjukkan bahwa informasi keberlanjutan memiliki hubungan signifikan dengan kinerja keuangan perusahaan dan nilai perusahaan (Atan et al. 2018; Buallay, 2019; Caesaria dan Basuki, 2017; Sila dan Cek, 2017; Velte, 2017). Informasi keberlanjutan muncul sebagai kebutuhan baru bagi investor dalam pertimbangan pengambilan keputusan ekonomi. Elemen keberlanjutan menjadi faktor penting dibandingkan dengan kinerja ekonomik pada masa kini (Caesaria dan Basuki, 2017; Cantele et al., 2018). Mengingat pentingnya informasi ini, evaluasi pengungkapan dalam sebuah informasi keberlanjutan dapat menjadi kerangka kerja baru terhadap pelaporan korporasi di Indonesia. Untuk menginvestigasi tingkat konformitas pengungkapan informasi keberlanjutan, penelitian ini menggunakan beberapa sistem penilaian terhadap item-item yang dilaporkan oleh perusahaan. Konformitas mengacu pada kesesuaian indikator-indikator dalam pedoman GRI untuk diterapkan dalam konteks pelaporan keberlanjutan di Indonesia. Desain indikator yang universal membuat perusahaan dapat mengungkapkan informasi keberlanjutan secara keseluruhan terlepas dari bentuk dan ukuran perusahaan (GRI 2013). Konformitas terjadi apabila informasi yang direpresentasikan dalam indikator-indikator GRI diungkapkan oleh perusahaan. Semakin banyak indikator yang diungkapkan, 
konformitas semakin tinggi. Konformitas dapat menjadi alat ukur keberterimaan indikator-indikator GRI dengan kondisi pelaporan di Indonesia. Selanjutnya, artikel ini akan ditulis berdasarkan struktur berikut. Tinjauan literatur dan landasan teori disajikan pada bagian 2. Bagian 3 nantinya akan

\section{TELAAH LITERATUR}

Pelaporan merupakan mekanisme perusahaan di mana dalam alat mengomunikasikan sebuah informasi finansial dan nonfinansial terhadap berbagai stakeholder. Pada awalnya, informasi yang dihasilkan hanya berfokus pada parameter ekonomi. Akan tetapi, praktik pelaporan korporasi telah berkembang lebih luas hingga fokus parameter nonekonomik seperti lingkungan dan sosial (Bhatia dan Tuli, 2018). Laporan keberlanjutan adalah laporan yang menyajikan informasi ekonomik, sosial dan lingkungan. Pelaporan keberlanjutan dapat membantu perusahaan dalam menetapkan objektif perusahaan, mengukur kinerja dan alat komunikasi dalam rangka menghadirkan operasi keberlanjutan (GRI 2013b). Laporan keberlanjutan menyajikan sampel, data dan metode riset untuk menginvestigasi tingkat konformitas dalam pengungkapan informasi. Bagian 4 mendeskripsikan analisis dari masing-masing aspek analisis. Bagian terakhir, bagian 5 nantinya akan menyimpulkan hasil dari penelitian ini.

berisi data sustainibilitas yang disajikan secara sistematis sehingga dapat dibandingkan terhadap masa lalu dan perkembangan terkait target pilihan yang dapat diukur (INTOSAI, 2013). Pelaporan keberlanjutan pada dasarnya telah dimulai sekitar dua puluh tahun yang lalu (Achim dan Borlea, 2015; Truant et al., 2017). Elkington (1998) merumuskan konsep populer dalam pengukuran kinerja perusahaan yang dikenal dengan sebutan triple bottom line (TBL). TBL mengajukan bahwa tujuan perusahaan tidak terlepas dari aktivitas sosial dan lingkungan dalam operasi perusahaan. TBL mengacu pada singkatan 3P yaitu people, profit and planet yang merupakan dimensi sustainibilitas klasik yaitu sosial, ekonomik, dan lingkungan. Ketiga dimensi ini telah diadopsi sebagai bagian dalam strategi 
keberlanjutan dalam laporan keberlanjutan. Laporan keberlanjutan memiliki banyak manfaat bagi korporasi. Laporan keberlanjutan dapat digunakan untuk menginformasikan sebuah lingkungan perusahaan dan menciptakan imej positif perusahaan kepada konsumen, pemasok dan masyarakat luas (Fazzini dan Maso 2016). Laporan keberlanjutan dikonsiderasikan sebagai alat komunikasi dan alat akuntabilitas perusahaan (Cantele et al., 2018). Berdasarkan uraian diatas, laporan keberlanjutan akan membawa pengaruh besar bagi perusahaan dalam mengelola dan mengungkapkan aktivitas operasional perusahaan dalam membangun perusahaan secara berkelangsungan dan keberlanjutan. Teori legitimasi dan stakeholder dipercaya menjadi teori dasar dalam praktik pelaporan keberlanjutan (Dienes et al 2016). Teori legitimasi berbasis gagasan (notion) bahwa bisnis beroperasi dalam masyarakat melalui kontrak sosial yang

\section{METODE PENELITIAN}

Desain penelitian ialah desain penelitian kualitatif dengan menggunakan teknik dokumentasi mewajibkan perusahaan melakukan berbagai tindakan yang secara sosial diperlukan dalam rangka mencapai tujuan, penghargaan (rewards) dan kelangsungan hidup mutakhir (ultimate survival) (Guthrie dan Parker, 1989). Laporan keberlanjutan dapat dipahami sebagai reaksi terhadap lingkungan masyarakat atas tindakan operasi perusahaan untuk melegitimasi tindakan-tindakan korporat. Sementara, Freeman (1984) berargumen bahwa konsep stakeholder dapat digunakan untuk proses pemahaman lebih baik pada level rasionalitas tertentu dalam menentukan grup dan individual mana yang dapat mempengaruhi dan dipengaruhi oleh aktivitas perusahaan. Konsep stakeholder diposisikan sebagai bagian dari manajemen strategis yang bertujuan mempererat hubungan perusahaan dengan pihakpihak berkepentingan baik internal dan eksternal dan mengembangkan keunggulan kompetitif.

dalam pengumpulan data. Analisis data menggunakan analisis isi (content analysis). Analisis isi adalah metode observasi penelitian yang 
digunakan untuk mengevaluasi konten segala bentuk catatan komunikasi secara sistematis (Sekaran dan Bougie, 2016). Analisis konten dapat digunakan dalam bentuk informasi tekstual dan secara sistematis mengidentifikasi berbagai konten seperti kata, konsep, karakter, tema dan kalimat.

\section{Populasi dan Sampel}

Populasi dalam penelitian ini adalah seluruh perusahaan terbuka di Indonesia yang menerbitkan laporan keberlanjutan tahun 2016. Jumlah perusahaan terbuka yang menerbitkan laporan keberlanjutan tahun 2016 ialah 57 perusahaan. Penelitian ini hanya menggunakan satu periode penelitian karena mengurangi dampak moderasi dari pelapor (reporters) yang berpengalaman dalam penelitian Truant et al. (2017) sehingga untuk perusahaan yang baru menerbitkan laporan keberlanjutan di tahun 2017 dikeluarkan dari sampel. Selain itu, studi satu periode juga diperlukan untuk mengontrol efek informasi lintas waktu yang dapat mempengaruhi pengukuran kualitas pelaporan keberlanjutan sehingga dalam penelitian ini hanya memasukkan perusahaan sebagai sampel apabila perusahaan sudah menerbitkan laporan keberlanjutan dalam dua atau tiga tahun sebelumnya (Tsalis et al., 2018). Dengan mempertimbangkan uraian diatas, didapatkan total sampel keseluruhan dalam penelitian ini sebanyak 29 perusahaan.

\section{Instrumen penelitian}

Instrumen yang digunakan dalam mengukur dimensi ekonomik, sosial, dan lingkungan adalah indikatorindikator yang ada dalam GRI G4 Guidelines. Indikator GRI diklaim memiliki validitas dan ketepatan yang lebih tinggi dibandingkan indikator lainnya (Bhatia dan Tuli, 2018; Cuesta dan Valor, 2013). Dalam analisis konformitas, indikator GRI G4 akan dinilai keberterimaannya pada kondisi pelaporan keberlanjutan di Indonesia karena menjadi panduan utama dalam pelaporan keberlanjutan. Pedoman GRI G4 mencakup dimensi ekonomik, sosial, dan lingkungan. Terdapat 47 kategori yang dirincikan kedalam 91 indikator pada pedoman GRI G4 yang 
menjelaskan item-item pengungkapan dalam keberlanjutan perusahaan. Dimensi ekonomik memiliki 4 kategori dalam 9 indikator. Dimensi lingkungan terdiri dari 12 kategori dalam 34 indikator. Sedangkan, dimensi sosial terdiri dari empat subdimensi yaitu sub-dimensi praktik ketenagakerjaan, hak asasi manusia, masyarakat, dan tanggungjawab produk. Subdimensi praktik ketenagakerjaan memiliki 8 kategori dalam 16 indikator. Subdimensi hak asasi manusia memiliki 10 kategori dalam 12 indikator. Subdimensi masyarakat memiliki 7 kategori dalam 11 indikator. Terakhir, subdimensi tanggungjawab produk terdiri dari 5 kategori dalam 9 indikator.

Teknik Pengumpulan Data

Data yang diperlukan dalam penelitian ini adalah data sekunder yang diolah dari laporan keberlanjutan perusahaan. Laporan keberlanjutan dapat diakses melalui website www.globalreporting.org dan website resmi masing-masing perusahaan. Dalam penelitian ini, tim pengumpul data akan terdiri dari tiga anggota termasuk peneliti yang mengevaluasi dan memberikan skor laporan keberlanjutan masing-masing perusahaan. Untuk memperkecil tingkat subjektivitas, beberapa metode digunakan salah satunya ialah pemberian pelatihan dan pertemuan rutin selama dua minggu. Pada sesi pemberian pelatihan, peneliti akan memperkenalkan kriteria evaluasi dan metode penelitian. Pertemuan rutin diperlukan untuk menyelesaikan keraguan dalam pemberian skor. Metode terakhir yang digunakan adalah dengan mengirimkan laporan pemberian skor kepada masingmasing perusahaan secara daring agar perusahaan dapat mengoreksi jika terdapat misinterpretasi dan kesalahpemahaman. Jika terdapat ketidaksetujuan, perusahaan dapat mengajukan keberatan dan informasi pendukung yang dapat digunakan untuk mengubah dan memodifikasi penilaian yang telah dilakukan. Jika perusahaan tidak merespon dalam jangka waktu yang ditentukan, maka perusahaan dianggap setuju dengan laporan pemberian skor yang diajukan oleh tim peneliti.

\section{Sistem Skor}

Berdasarkan uraian di atas, konformitas dianalisis dalam dua 
tingkatan. Tingkat pertama menggunakan skala dummy yaitu indikator diberikan nilai 1 jika diungkapkan perusahaan dan nilai 0 jika tidak diungkapkan perusahaan. Sementara pada tingkatan kedua, setiap indikator akan dianalisis secara komprehensif. Indikator dinilai dengan mengukur seberapa penuh perusahaan mengungkapkan informasi dalam satuan persentase. Contohnya, indikator G4-EC9 yang diuraikan sebagai berikut:

1. Laporkan persentase anggaran pengadaan yang digunakan di lokasi operasi yang signifikan yang dibelanjakan pada pemasok lokal pada operasi yang dimaksud (seperti persentase produk dan jasa yang dibeli secara lokal).

2. Laporkan definisi geografis organisasi tentang 'lokal'.

3. Laporkan definisi yang digunakan untuk 'lokasi operasi yang signifikan'.

Jika sebuah perusahaan hanya mengungkapkan satu poin saja dalam laporan keberlanjutan maka, konformitas indikator diberikan nilai
$33,3 \%$ (hanya satu poin dari tiga poin). Nilai ini akan dirata-ratakan untuk seluruh perusahaan dan diatributkan ke indikator tersebut sebagai nilai konformitas.

\section{HASIL PENELITIAN DAN PEMBAHASAN}

Konformitas Tingkat I

Analisis konformitas tingkat I menunjukkan apakah indikatorindikator dalam pedoman GRI G4 dapat diterapkan di Indonesia secara praktis. Konformitas terjadi apabila perusahaan mampu mengungkapkan indikator GRI dalam laporan keberlanjutannya di mana nantinya tanpa memperhatikan seberapa banyak informasi yang disampaikan melalui indikator tersebut. Konformitas tingkat I menguji apakah tema-tema keberlanjutan yang sudah disusun dalam 91 indikator relevan dengan kondisi perusahaan-perusahaan di Indonesia. Dalam analisis konformitas tingkat I, hasil yang diharapkan adalah mengetahui seberapa banyak indikator yang nantinya di munculkan atau dilaporkan oleh perusahaan di Indonesia dan 
indikator subtema apa yang paling sering dimunculkan antar perusahaan. Informasi ekonomik mendominasi dalam pengungkapan informasi keberlanjutan (ditinjau dari segi kemunculannya). Indikator ekonomik lebih sering diungkapkan dalam pelaporan keberlanjutan dengan tingkat kemunculan $44,1 \%$. Tanpa memandang substansi informasi yang diungkapkan, informasi ekonomik menjadi pilihan 'favorit' bagi pemangku kepentingan dalam hal materialitas informasi keberlanjutan. Indikator ekonomik juga tidak memiliki indikator nihil. Hal ini berarti ke-sembilan indikator memiliki konformitas dasar karena diungkapkan seluruhnya. Pernyataan ini juga didukung dengan indikator EC1 yang tingkat kemunculannya paling tinggi dibandingkan seluruh indikator GRI dengan tingkat 89,7\%. Informasi ekonomik yang dimunculkan perusahaan masih berfokus pada kinerja ekonomi utama dan ekonomi tidak langsung. Perusahaan dalam sampel juga masih represif untuk memunculkan informasi ekonomik lain, seperti keberadaan di pasar dan praktik pengadaan. Dapat diambil kesimpulan bahwa tema ekonomik yang direpresentasikan dalam indikator-indikator GRI G4 cukup mendapat perhatian bagi pelaku industri di Indonesia dengan dimunculkannya seluruh indikator pada sampel penelitian. Indikator ekonomik terbukti masih relevan dalam pelaporan keberlanjutan perusahaan di Indonesia. Penyajian informasi yang familiar tidak membuat perusahaan kesulitan untuk menerapkan indikator ekonomik dibandingkan indikator keberlanjutan lainnya. Indikator lingkungan menjadi indikator dengan tingkat kemunculan terendah sebesar $24,5 \%$. Hasil ini juga sejalan dengan banyaknya jumlah indikator nihil sebanyak 2 (dari 34 indikator). Temuan ini mengindikasikan bahwa isu lingkungan bukan menjadi isu utama dalam penetapan informasi keberlanjutan. Indikator lingkungan sendiri sebenarnya sulit diterapkan sepenuhnya bagi perusahaan. Contohnya perusahaan finansial yang tidak secara langsung berhubungan dengan elemen lingkungan dan bahan baku. Jadi, rendahnya konformitas indikator lingkungan masih disebabkan oleh aspek non- 
teknis dan non-praktis yang tidak dikontrol dalam analisis konformitas. Informasi mengenai konsumsi energi (EN3) menjadi informasi yang paling sering muncul dalam pelaporan keberlanjutan di Indonesia. Sebanyak sebesar 69,0\% laporan dalam objek penelitian mengungkapkan informasi tersebut. Indikator EN3 membahas konsumsi energi dalam perusahaan.
Hal ini menunjukan indikator ini memiliki frekuensi pengungkapan tinggi karena rata-rata perusahaan mengungkapkan konsumsi energi listrik, AC dan pendingin yang merupakan jenis energi umum yang aplikabel pada seluruh perusahaan. Perusahaan di Indonesia cukup memperhatikan aspek energi, emisi, dan air.

Tabel 1 Konformitas Tingkat 1 Seluruh Indikator

\begin{tabular}{cccccccc}
$\begin{array}{c}\text { Jumlah } \\
\text { Pengungkapan }\end{array}$ & $\begin{array}{c}\text { Proporsi } \\
\text { Sampel }\end{array}$ & $\begin{array}{c}\text { Indikator } \\
\text { GRI }\end{array}$ & $\begin{array}{c}\text { Jumlah } \\
\text { Pengungkapan }\end{array}$ & $\begin{array}{c}\text { Proporsi } \\
\text { Sampel }\end{array}$ & $\begin{array}{c}\text { Indikator } \\
\text { GRI }\end{array}$ & $\begin{array}{c}\text { Jumlah } \\
\text { Pengungkapan }\end{array}$ & $\begin{array}{c}\text { Proporsi } \\
\text { Sampel }\end{array}$ \\
\hline 26 & $89.7 \%$ & G4-EN22 & 10 & $34.5 \%$ & G4-HR2 & 3 & $10.3 \%$ \\
7 & $24.1 \%$ & G4-EN23 & 12 & $41.4 \%$ & G4-HR3 & 7 & $24.1 \%$ \\
8 & $27.6 \%$ & G4-EN24 & 6 & $20.7 \%$ & G4-HR4 & 8 & $27.6 \%$ \\
7 & $24.1 \%$ & G4-EN25 & 3 & $10.3 \%$ & G4-HR5 & 5 & $17.2 \%$ \\
11 & $37.9 \%$ & G4-EN26 & 1 & $3.4 \%$ & G4-HR6 & 5 & $17.2 \%$ \\
3 & $10.3 \%$ & G4-EN27 & 8 & $27.6 \%$ & G4-HR7 & 4 & $13.8 \%$ \\
21 & $72.4 \%$ & G4-EN28 & 2 & $6.9 \%$ & G4-HR8 & 2 & $6.9 \%$ \\
25 & $86.2 \%$ & G4-EN29 & 11 & $37.9 \%$ & G4-HR9 & 0 & $0.0 \%$ \\
7 & $24.1 \%$ & G4-EN30 & 3 & $10.3 \%$ & G4-HR10 & 4 & $13.8 \%$ \\
8 & $27.6 \%$ & G4-EN31 & 10 & $34.5 \%$ & G4-HR11 & 1 & $3.4 \%$ \\
6 & $20.7 \%$ & G4-EN32 & 6 & $20.7 \%$ & G4-HR12 & 4 & $13.8 \%$ \\
20 & $69.0 \%$ & G4-EN33 & 0 & $0.0 \%$ & G4-SO1 & 24 & $82.8 \%$ \\
2 & $6.9 \%$ & G4-EN34 & 5 & $17.2 \%$ & G4-SO2 & 4 & $13.8 \%$ \\
12 & $41.4 \%$ & G4-LA1 & 21 & $72.4 \%$ & G4-SO3 & 12 & $41.4 \%$ \\
\hline
\end{tabular}


Tabel 2 Konfirmitas Tingkat 1 Seluruh Indikator

\begin{tabular}{cccccccc}
\hline $\begin{array}{c}\text { Jumlah } \\
\text { Pengungkapan }\end{array}$ & $\begin{array}{c}\text { Proporsi } \\
\text { Sampel }\end{array}$ & $\begin{array}{c}\text { Indikator } \\
\text { GRI }\end{array}$ & $\begin{array}{c}\text { Jumlah } \\
\text { Pengungkapan }\end{array}$ & $\begin{array}{c}\text { Proporsi } \\
\text { Sampel }\end{array}$ & $\begin{array}{c}\text { Indikator } \\
\text { GRI }\end{array}$ & $\begin{array}{c}\text { Jumlah } \\
\text { Pengungkapan }\end{array}$ & $\begin{array}{c}\text { Proporsi } \\
\text { Sampel }\end{array}$ \\
\hline 15 & $51.7 \%$ & G4-LA2 & 15 & $51.7 \%$ & G4-SO4 & 20 & $69.0 \%$ \\
3 & $10.3 \%$ & G4-LA3 & 9 & $31.0 \%$ & G4-SO5 & 15 & $51.7 \%$ \\
16 & $55.2 \%$ & G4-LA4 & 7 & $24.1 \%$ & G4-SO6 & 5 & $17.2 \%$ \\
4 & $13.8 \%$ & G4-LA5 & 12 & $41.4 \%$ & G4-SO7 & 5 & $17.2 \%$ \\
6 & $20.7 \%$ & G4-LA6 & 22 & $75.9 \%$ & G4-SO8 & 8 & $27.6 \%$ \\
6 & $20.7 \%$ & G4-LA7 & 10 & $34.5 \%$ & G4-SO9 & 3 & $10.3 \%$ \\
4 & $13.8 \%$ & G4-LA8 & 8 & $27.6 \%$ & G4-SO10 & 0 & $0.0 \%$ \\
9 & $31.0 \%$ & G4-LA9 & 22 & $75.9 \%$ & G4-SO11 & 3 & $10.3 \%$ \\
8 & $27.6 \%$ & G4-LA10 & 12 & $41.4 \%$ & G4-PR1 & 7 & $24.1 \%$ \\
8 & $27.6 \%$ & G4-LA11 & 15 & $51.7 \%$ & G4-PR2 & 6 & $20.7 \%$ \\
7 & $24.1 \%$ & G4-LA12 & 8 & $27.6 \%$ & G4-PR3 & 10 & $34.5 \%$ \\
0 & $0.0 \%$ & G4-LA13 & 7 & $24.1 \%$ & G4-PR4 & 8 & $27.6 \%$ \\
9 & $31.0 \%$ & G4-LA14 & 5 & $17.2 \%$ & G4-PR5 & 19 & $65.5 \%$ \\
15 & $51.7 \%$ & G4-LA15 & 3 & $10.3 \%$ & G4-PR6 & 4 & $13.8 \%$ \\
2 & $6.9 \%$ & G4-LA16 & 4 & $13.8 \%$ & G4-PR7 & 7 & $24.1 \%$ \\
5 & $17.2 \%$ & G4-HR1 & 0 & $0.0 \%$ & G4-PR8 & 13 & $44.8 \%$ \\
\hline
\end{tabular}

Tabel 3 Konfirmitas Tingkat 1 Seluruh Indikator

\begin{tabular}{cccc}
\hline & $\begin{array}{c}\text { Informasi } \\
\text { Ekonomik }\end{array}$ & $\begin{array}{c}\text { Informasi } \\
\text { Lingkungan }\end{array}$ & $\begin{array}{c}\text { Informasi } \\
\text { Sosial }\end{array}$ \\
\hline $\begin{array}{c}\text { Tingkat kemunculan } \\
\text { rata-rata }\end{array}$ & $44.1 \%$ & $24.5 \%$ & $29.1 \%$ \\
$\begin{array}{c}\text { Jumlah indikator yang tidak } \\
\text { diungkapkan }\end{array}$ & $0 / 9$ & $3 / 34$ & $3 / 48$ \\
Tingkat kemunculan tertinggi & $\begin{array}{c}\text { G4-EC1 } \\
(89,7 \%)\end{array}$ & $\begin{array}{c}\text { G4-EN6 } \\
(69,0 \%)\end{array}$ & $\begin{array}{c}\text { G4-SO1 } \\
(82,8 \%)\end{array}$ \\
\hline
\end{tabular}

Dengan tingginya tingkat laporan keberlanjutan perusahaan kemunculan indikator dalam laporan Indonesia. Indikator sosial keberlanjutan. Akan tetapi, informasi memiliki tingkat kemunculan sebesar mengenai keanekaragaman hayati, bahan material, transportasi dan efluen kurang mendapat perhatian dari stakeholder Indonesia. Secara umum dapat disimpulkan bahwa tema lingkungan yang ada dalam indikator GRI masih cukup sesuai dengan kultur keberlanjutan di Indonesia dengan banyaknya kemunculan indikator tersebut dalam 29,1\%. Untuk dimensi dengan indikator terbanyak (48 indikator), angka $29,1 \%$ mengindikasikan kesesuaian yang cukup rendah. Namun, terdapat tiga indikator yang tidak diungkapkan oleh objek penelitian. Konformitas indikator sosial juga didukung dengan banyaknya indikator yang memiliki frekuensi kemunculan tinggi (diatas 
$50 \%$ ) yaitu sebanyak 9 indikator. Informasi sosial dalam pedoman GRI dikelompokkan menjadi empat subdimensi, yaitu subdimensi ketenagakerjaan, hak asasi manusia, masyarakat, dan produk. subdimensi ketenagakerjaan menjadi indikator yang paling sering muncul dalam pengungkapan informasi sosial dibandingkan dengan tiga subdimensi lainnya. Subdimensi ketenagakerjaan memiliki proporsi kemunculan sebesar $100 \%$ dengan tingkat kemunculan sebesar 38,8\%. Subdimensi yang paling kurang konformitasnya ialah subdimensi hak asasi manusia. Terdapat dua indikator hak asasi manusia yang tidak muncul dalam laporan mana pun, yaitu mengenai klausul HAM dalam kontrak (HR1) dan asesmen dampak HAM dalam operasi perusahaan (HR9). Hal ini diperburuk dengan tingkat kemunculan yang hanya sebesar $12,4 \%$. Nilai ini merupakan nilai yang paling rendah dibandingkan dengan indikator lainnya. Sementara untuk subdimensi masyarakat dan produk \& jasa memiliki tingkat kemunculan yang relatif sama, yaitu
$31 \%$, namun terdapat satu indikator subdimensi masyarakat mengenai asesmen pemasok (SO10) yang tidak kompatibel di Indonesia. Secara keseluruhan, hasil konformitas tingkat I menunjukkan bahwa informasi ekonomik mengungguli informasi keberlanjutan lain dalam hal frekuensi dan keterlaporannya. Hasil ini berbeda dengan penelitian Ching dan Gerab (2016) yang menyimpulkan bahwa indikator sosial yang paling sering dimunculkan dalam praktik pelaporan keberlanjutan di Brazil. Tingkat kemunculan yang tinggi mengindikasikan indikator ekonomik lebih dapat diterapkan di Indonesia dibanding indikator lainnya. Akan tetapi, analisis konformitas tingkat I hanya menguji pada tingkat frekuensi belum pada isi suatu informasi. Analisis konformitas tingkat I perlu ditunjang dengan analisis selanjutnya karena analisis ini tidak mempertimbangkan spesifikasi informasi yang disampaikan perusahaan. Analisis konformitas tingkat I hanya digunakan untuk mengetahui tingkat kemunculan indikator GRI dalam 
praktik pelaporan keberlanjutan di Indonesia dan memahami pola kemunculannya yang sifatnya probabilistik. Analisis selanjutnya mempertimbangkan bobot informasi yang disampaikan perusahaan dalam menguji konstruk konformitas yang lebih dalam lagi.

\section{Konformitas Tingkat II}

Analisis konformitas tingkat II bertujuan untuk mengetahui keberterimaan indikator-indikator dalam pedoman GRI G4 pada praktik pelaporan keberlanjutan di Indonesia. Analisis ini mengukur tingkat kesesuaian parsial dan tingkat kesesuaian total. Tingkat kesesuaian parsial mengukur seberapa sesuai informasi keberlanjutan disajikan oleh perusahaan yang hanya mengungkapkan informasi tersebut. Sementara tingkat kesesuaian total mengukur seberapa sesuai informasi yang diungkapkan oleh seluruh perusahaan dalam objek penelitian. Tabel 2 menyajikan ringkasan konformitas tingkat II. Indikator ekonomik menjadi informasi dengan konformitas paling tinggi dibanding indikator dengan dimensi lainnya. Dimensi ekonomik memiliki tingkat kesesuaian parsial dan total yang lebih tinggi dibandingkan indicator lainnya. Hasil ini menegaskan menujukan bahwa dalam konteks pelaporan keberlanjutan di Indonesia, di mana indikatorindikator ekonomik lebih sesuai dan lebih relevan untuk diaplikasikan oleh perusahaan di Indonesia. Tingkat kesesuaian parsial sebesar $68,2 \%$ juga cenderung tinggi yang mengindikasikan tidak sulitnya indikator ekonomik untuk diungkapkan. Temuan ini menegaskan dimensi ekonomik menjadi dimensi keberlanjutan yang paling sesuai di Indonesia dibanding dimensi lainnya. Tingkat kesesuaian parsial indikator ekonomik ialah sebesar $68,2 \%$. Artinya, perusahaan yang mengungkapkan indikator ekonomik dalam laporan keberlanjutan akan menyampaikan $68,2 \%$ informasi per indikatornya. Namun, nilai kesesuaian total indikator ekonomik hanya mencapai $31,9 \%$. Nilai ini menginterpretasikan bahwa bobot informasi ekonomik yang disampaikan oleh seluruh perusahaan di Indonesia ialah sebesar $31,9 \%$ per indikatornya. Tingkat kesesuaian total tertinggi 
ialah indikator EC8 (dampak ekonomi tidak langsung). Hasil ini berbeda dengan analisis konformitas tingkat I yang menunjukkan indikator EC1 (nilai ekonomi langsung) sebagai indikator yang paling sering dimunculkan perusahaan. Jika ditinjau dari bobot informasi, indikator EC8 menjadi indikator yang memiliki konformitas paling tinggi diantara indikator ekonomik. Hal ini menegaskan bahwa operasi perusahaan di Indonesia memiliki dampak ekonomi tidak langsung yang signifikan. Dampak ini dapat berasal dari perubahan lokasi operasional, penggunaan produk dan jasa, stimulasi dan membatasi investasi asing langsung, dan perkembangan ekonomi di daerah dengan tingkat kemiskinan tinggi. Banyaknya jenis dampak ekonomi tidak langsung yang dapat terjadi berdampak pada kemudahan perusahaan dalam menyampaikan informasi. Nilai konformitas terendah ialah indikator EC6 dengan tingkat kesesuaian total hanya sebesar 3,4\%. Indikator EC6 mensyaratkan bahwa informasi perbandingan manajemen senior dari masyarakat lokal. Rendahnya tingkat kesesuaian menunjukkan bahwa perusahaan di Indonesia jarang menggunakan masyarakat lokal dalam jajaran manajemen senior sehingga perusahaan tidak dapat mengungkapkan informasi tersebut. Dari hasil deskripsi data, indikator lingkungan memiliki tingkat kesesuaian parsial sebesar 54,4\% dan tingkat kesesuaian total hanya sebesar $14,8 \%$. Rendahnya tingkat kesesuaian menunjukkan bahwa hal ini menunjukan indikator-indikator lingkungan dalam pedoman GRI G4 memiliki konformitas rendah dan sulit diimplementasikan seluruhnya di Indonesia. Tingkat kesesuaian total tertinggi ialah indikator EN29 (nilai moneter denda ketidakpatuhan). Perusahaan di Indonesia cenderung patuh dan tidak menghadapi denda terkait ketidakpatuhan terhadap peraturan lingkungan. Seluruh perusahaan bahkan menyebutkan tidak menerima denda terkait pelanggaran aturan lingkungan. Hasil ini berbeda dengan hasil konfomitas tingkat I yang menunjukkan indikator EN3 (konsumsi energi) menjadi indikator 
yang paling sering dimunculkan. Meskipun indikator EN3 sering ditampilkan, perusahaan tidak menyajikan informasi secara penuh. Indikator EN3 cukup sulit ditampilkan secara penuh karena tidak semua perusahaan memiliki kriteria yang dipersyaratkan misalnya tidak semua perusahaan memiliki energi terbaharukan dan tidak terbaharukan. Jadi, walaupun indikator ini relatif dapat digunakan oleh seluruh perusahaan, tetapi pemenuhan informasi yang dipersyaratkan lebih sulit direalisasi baik karena alasan tidak dapat diterapkan mau pun sulit diungkapkan. Tingkat kesesuaian parsial indikator sosial adalah sebesar $62,3 \%$ dan tingkat kesesuaian total sebesar 19,5\%. Sejalan dengan hasil konformitas tingkat I, indikator SO1 (program pengembangan masyarakat lokal) juga menjadi indikator dengan tingkat kesesuaian total paling tinggi sebesar 75,9\% (data lengkap ada dalam Lampiran 9). Indikator SO1 sebelumnya menjadi indikator dengan tingkat kemunculan paling tinggi. Hal ini menegaskan bahwa program pengembangan dan pelibatan masyarakat lokal menjadi prioritas perusahaan dalam mempertahankan keberlangsungan usaha dan meraih legitimasi indikator ini juga sejalan dengan pengaturan mengenai pengungkapan tanggung jawab sosial yang ada di Indonesia sehingga tidak sulit untuk mengungkapkan indikator ini secara penuh. Dimensi sosial memiliki tiga indikator dengan tingkat konformitas $0 \%$, yaitu indikator HR1, HR9, dan SO10. Indikator HR1 dan HR9 membahas terkait dengan klausul hak asasi manusia dalam kontrak kerja dan operasi perusahaan. Jika dilihat dari aspek pengungkapan saja, belum ada perusahaan di Indonesia yang mengikutsertakan klausul terkait hak asasi dalam kontrak kerja dan asesmen operasi. Hal ini membuat informasi hak asasi manusia menjadi sangat rendah baik per indikator maupun secara agregat. Temuan ini diperkuat dengan tidak adanya pengaturan mengenai hak asasi manusia dalam POJK No. 29/POJK.04/2016 tentang Laporan Tahunan Emiten atau Perusahaan Publik sehingga klausul mengenai HAM menjadi informasi kelas dua dalam pelaporan korporasi. Indikator 
SO10 membahas mengenai dampak negatif signifikan terhadap pemasok. Sama halnya dengan indikator EN33, hal ini dapat dijelaskan karena masih kecil jumlah perusahaan yang menggunakan kriteria sosial dalam memilih pemasok sehingga pengukuran dampak negatif tidak dapat dilakukan. Hasil yang menarik ditunjukkan dengan lebarnya gap antara tingkat kesesuaian parsial dan total pada seluruh dimensi keberlanjutan. Nilai selisih indikator ekonomik mencapai 36,3\%, indikator sosial sebesar $42,9 \%$ dan indikator lingkungan $39,6 \%$. Tingginya nilai selisih menunjukkan masih banyak indikator yang tidak diungkapkan perusahaan. Hasil ini tidak cukup menyenangkan karena investor akan kesulitan dalam asesmen informasi keberlanjutan karena disatu sisi, untuk indikator yang diungkapkan memberikan bobot informasi baik tetapi banyak indikator yang tidak diungkapkan sehingga tidak memberikan informasi tentang apapun.

Tabel 4 Konfirmitas Tingkat II Seluruh Indikator

\begin{tabular}{ccccccccc}
$\begin{array}{c}\text { Indikator } \\
\text { GRI }\end{array}$ & $\begin{array}{c}\text { Tingkat } \\
\text { Kesesuaian }\end{array}$ & $\begin{array}{c}\text { Tingkat } \\
\text { Kesesuaian }\end{array}$ & $\begin{array}{c}\text { Indikator } \\
\text { GRI }\end{array}$ & $\begin{array}{c}\text { Tingkat } \\
\text { Kesesuaian }\end{array}$ & $\begin{array}{c}\text { Tingkat } \\
\text { Kesesuaian }\end{array}$ & $\begin{array}{c}\text { Indikator } \\
\text { GRI }\end{array}$ & $\begin{array}{c}\text { Tingkat } \\
\text { Kesesuaian }\end{array}$ & $\begin{array}{c}\text { Tingkat } \\
\text { Kesesuaian }\end{array}$ \\
\hline G4-EC1 & $69.2 \%$ & $62.1 \%$ & G4-EN22 & $69.4 \%$ & $21.6 \%$ & G4-HR2 & $33.3 \%$ & $3.4 \%$ \\
G4-EC2 & $85.7 \%$ & $20.7 \%$ & G4-EN23 & $45.3 \%$ & $23.4 \%$ & G4-HR3 & $85.7 \%$ & $20.7 \%$ \\
G4-EC3 & $50.0 \%$ & $13.8 \%$ & G4-EN24 & $25.0 \%$ & $1.7 \%$ & G4-HR4 & $81.3 \%$ & $22.4 \%$ \\
G4-EC4 & $95.2 \%$ & $23.0 \%$ & G4-EN25 & $50.0 \%$ & $10.3 \%$ & G4-HR5 & $100.0 \%$ & $17.2 \%$ \\
G4-EC5 & $51.5 \%$ & $19.5 \%$ & G4-EN26 & $50.0 \%$ & $17.2 \%$ & G4-HR6 & $90.0 \%$ & $15.5 \%$ \\
G4-EC6 & $33.3 \%$ & $3.4 \%$ & G4-EN27 & $70.8 \%$ & $29.3 \%$ & G4-HR7 & $100.0 \%$ & $13.8 \%$ \\
G4-EC7 & $84.1 \%$ & $60.9 \%$ & G4-EN28 & $83.3 \%$ & $17.2 \%$ & G4-HR8 & $100.0 \%$ & $6.9 \%$ \\
G4-EC8 & $78.0 \%$ & $67.2 \%$ & G4-EN29 & $16.7 \%$ & $1.7 \%$ & G4-HR9 & $0.0 \%$ & $0.0 \%$ \\
G4-EC9 & $66.7 \%$ & $16.1 \%$ & G4-EN30 & $0.0 \%$ & $0.0 \%$ & G4-HR10 & $50.0 \%$ & $6.9 \%$ \\
G4-EN1 & $75.0 \%$ & $20.7 \%$ & G4-EN31 & $37.5 \%$ & $10.3 \%$ & G4-HR11 & $20.0 \%$ & $0.7 \%$ \\
G4-EN2 & $66.7 \%$ & $13.8 \%$ & G4-EN32 & $25.0 \%$ & $1.7 \%$ & G4-HR12 & $83.3 \%$ & $11.5 \%$ \\
G4-EN3 & $31.4 \%$ & $21.7 \%$ & G4-EN33 & $100.0 \%$ & $37.9 \%$ & G4-SO1 & $91.7 \%$ & $75.9 \%$ \\
G4-EN4 & $100.0 \%$ & $6.9 \%$ & G4-EN34 & $11.1 \%$ & $1.1 \%$ & G4-SO2 & $100.0 \%$ & $13.8 \%$ \\
G4-EN5 & $45.8 \%$ & $19.0 \%$ & G4-LA1 & $76.2 \%$ & $55.2 \%$ & G4-SO3 & $16.7 \%$ & $6.9 \%$ \\
G4-EN6 & $51.7 \%$ & $26.7 \%$ & G4-LA2 & $66.7 \%$ & $34.5 \%$ & G4-SO4 & $12.0 \%$ & $8.3 \%$ \\
G4-EN7 & $22.2 \%$ & $2.3 \%$ & G4-LA3 & $68.9 \%$ & $21.4 \%$ & G4-SO5 & $60.0 \%$ & $31.0 \%$ \\
G4-EN8 & $56.3 \%$ & $31.0 \%$ & G4-LA4 & $50.0 \%$ & $12.1 \%$ & G4-SO6 & $90.0 \%$ & $15.5 \%$ \\
\hline
\end{tabular}


Tabel 5 Konfirmitas Tingkat II Seluruh Indikator

\begin{tabular}{ccccccccc}
$\begin{array}{c}\text { Indikator } \\
\text { GRI }\end{array}$ & $\begin{array}{c}\text { Tingkat } \\
\text { Kesesuaian }\end{array}$ & $\begin{array}{c}\text { Tingkat } \\
\text { Kesesuaian }\end{array}$ & $\begin{array}{c}\text { Indikator } \\
\text { GRI }\end{array}$ & $\begin{array}{c}\text { Tingkat } \\
\text { Kesesuaian }\end{array}$ & $\begin{array}{c}\text { Tingkat } \\
\text { Kesesuaian }\end{array}$ & $\begin{array}{c}\text { Indikator } \\
\text { GRI }\end{array}$ & $\begin{array}{c}\text { Tingkat } \\
\text { Kesesuaian }\end{array}$ & $\begin{array}{c}\text { Tingkat } \\
\text { Kesesuaian }\end{array}$ \\
\hline G4-EN9 & $50.0 \%$ & $6.9 \%$ & G4-LA5 & $79.2 \%$ & $32.8 \%$ & G4-SO7 & $60.0 \%$ & $10.3 \%$ \\
G4-EN10 & $55.6 \%$ & $11.5 \%$ & G4-LA6 & $60.6 \%$ & $46.0 \%$ & G4-SO8 & $91.7 \%$ & $25.3 \%$ \\
G4-EN11 & $100.0 \%$ & $20.7 \%$ & G4-LA7 & $70.0 \%$ & $24.1 \%$ & G4-SO9 & $33.3 \%$ & $3.4 \%$ \\
G4-EN12 & $87.5 \%$ & $12.1 \%$ & G4-LA8 & $62.5 \%$ & $17.2 \%$ & G4-SO10 & $0.0 \%$ & $0.0 \%$ \\
G4-EN13 & $75.0 \%$ & $23.3 \%$ & G4-LA9 & $81.8 \%$ & $62.1 \%$ & G4-SO11 & $22.2 \%$ & $2.3 \%$ \\
G4-EN14 & $87.5 \%$ & $24.1 \%$ & G4-LA10 & $70.8 \%$ & $29.3 \%$ & G4-PR1 & $14.3 \%$ & $3.4 \%$ \\
G4-EN15 & $42.9 \%$ & $11.8 \%$ & G4-LA11 & $46.7 \%$ & $24.1 \%$ & G4-PR2 & $100.0 \%$ & $20.7 \%$ \\
G4-EN16 & $52.4 \%$ & $12.6 \%$ & G4-LA12 & $68.8 \%$ & $19.0 \%$ & G4-PR3 & $33.3 \%$ & $10.3 \%$ \\
G4-EN17 & $0.0 \%$ & $0.0 \%$ & G4-LA13 & $21.4 \%$ & $5.2 \%$ & G4-PR4 & $93.8 \%$ & $25.9 \%$ \\
G4-EN18 & $69.4 \%$ & $21.6 \%$ & G4-LA14 & $60.0 \%$ & $10.3 \%$ & G4-PR5 & $89.5 \%$ & $58.6 \%$ \\
G4-EN19 & $45.3 \%$ & $23.4 \%$ & G4-LA15 & $40.0 \%$ & $4.1 \%$ & G4-PR6 & $75.0 \%$ & $10.3 \%$ \\
G4-EN20 & $25.0 \%$ & $1.7 \%$ & G4-LA16 & $75.0 \%$ & $10.3 \%$ & G4-PR7 & $100.0 \%$ & $24.1 \%$ \\
G4-EN21 & $50.0 \%$ & $10.3 \%$ & G4-HR1 & $0.0 \%$ & $0.0 \%$ & G4-PR8 & $66.7 \%$ & $29.9 \%$ \\
& & & & & & G4-PR9 & $100.0 \%$ & $31.0 \%$ \\
\hline
\end{tabular}

Tabel 6 Konfirmitas Tingkat II Seluruh Indikator

\begin{tabular}{ccccc}
\hline & $\begin{array}{c}\text { Informasi } \\
\text { Ekonomik }\end{array}$ & $\begin{array}{c}\text { Informasi } \\
\text { Lingkungan }\end{array}$ & $\begin{array}{c}\text { Informasi } \\
\text { Sosial }\end{array}$ & Keseluruhan \\
\hline $\begin{array}{c}\text { Tingkat } \\
\text { Kesesuaian }\end{array}$ & & & & \\
Parsial & $68.2 \%$ & $54.4 \%$ & $62.3 \%$ & $60.0 \%$ \\
Tingkat & & & & \\
Kesesuaian & & & & \\
Total & $31.9 \%$ & $14.8 \%$ & $19.5 \%$ & $19.0 \%$ \\
Selisih & $36.3 \%$ & $39.6 \%$ & $42.9 \%$ & $41.0 \%$ \\
\hline
\end{tabular}

Tingkat kesesuaian parsial dimaknai bahwa sebenarnya keseluruhan ialah $60,0 \%$ sementara perusahaan menyampaikan informasi tingkat kesesuaian total keseluruhan keberlanjutan dengan bobot hanya sebesar $19,0 \%$. Tingkat parsial informasi yang baik namun diukur dengan merata-ratakan bobot perusahaan tidak mampu untuk informasi per indikator yang disampaikan bagi perusahaan yang menyampaikan saja. Sementara tingkat total diukur dengan merataratakan bobot informasi seluruh objek penelitian. Lebarnya gap dapat memunculkan lebih banyak indikator keberlanjutan. Hal ini disebabkan oleh beberapa faktor seperti tidak sesuainya indikator dengan core business dalam sebuah perusahaan, ketidaktersediaannya dalam sebuah 
data, kurangnya materialitas informasi dan kecenderungan kebutuhan informasi stakeholder. Jadi, kesesuaian penyampaian informasi yang dilakukan perusahaan untuk indikator-indikator yang telah diungkapkannya ialah cukup baik namun jumlah indikator yang disampaikan masih kurang. persentase tersebut, sulit tentunya untuk mendapatkan tingkat kesesuaian total yang tinggi. Simulasi sederhana jika 26,3 indikator diungkapkan secara penuh $100 \%$, maka tingkat kesesuaian total hanya mencapai $28,9 \%$. Sehingga dalam temuan penelitian, indikator ekonomik overvalued dalam artian baik. Dengan gap sebesar 41,0\%, indikator GRI benar-benar tidak dapat diterapkan secara penuh di

\section{SIMPULAN}

Laporan keberlanjutan merupakan media yang digunakan perusahaan dalam melaporkan informasi ekonomik, sosial, dan lingkungan. Penelitian ini menganalisis laporan keberlanjutan dalam aspek konformitas dalam pengungkapan informasi. Aspek konformitas
Rasionalisasi temuan konformitas tingkat II didukung dengan hasil konformitas tingkat I. Dalam analisis konformitas tingkat I, dapat dilihat bahwa rata-rata setiap perusahaan dalam objek penelitian hanya menyampaikan 26,3 indikator dari 91 indikator $28,9 \%$ konformitas tingkat I di mana dengan Indonesia. Jadi dapat disimpulkan bahwa, jika hasil analisis konformitas tingkat I tidak menunjukkan hasil yang positif secara material maka hasil analisis konformitas tingkat II juga tidak akan menghasilkan nilai yang positif secara material pula. Hasil ini sejalan dengan penelitian yang dilakukan oleh Khan et al. (2011) dan Cuesta dan Valor (2013).

mengukur keberterimaan indikator GRI G4 di Indonesia. Aspek konformitas dapat digunakan untuk mengindikasikan apakah indikator keberlanjutan pada pedoman GRI dapat diterapkan di Indonesia. Hasil penelitian ini menunjukkan tingkat konformitas indikator keberlanjutan GRI G4 kurang berterima dalam 
praktik pelaporan keberlanjutan. Rendahnya tingkat kemunculan dan kesesuaian dalam analisis konformitas menunjukkan bahwa indikator GRI G4 tidak dapat diungkapkan sepenuhnya dalam konteks Indonesia. Beberapa indikator juga ditemukan tidak pernah disajikan dalam laporan keberlanjutan di perusahaan manapun sehingga berdampak pada rendahnya konformitas. Namun, jika dilihat dari konformitas indikator yang ditampilkan perusahaan saja maka tingkat konformitas dipenuhi dengan cukup baik. Keterbatasan utama dalam penelitian ini adalah

\section{DAFTAR PUSTAKA}

Achim, M.-V., \& Borlea, S. N. (2015). Developing of ESG Score to Assess the Nonfinancial Performances in Romanian Companies. Procedia Economics and Finance, 32, 1209-1224. https://doi.org/10.1016/S221 2-5671(15)01499-9

Al-Dah, B., Dah, M., \& Jizi, M. (2018). Is CSR reporting always favorable? Management Decision, 56 (7), 1506-1525. https://doi.org/10.1108/MD05-2017-0540. penelitian ini tidak memiliki cukup banyak objek penelitian. Jumlah objek penelitian yang hanya mencakup 29 perusahaan hanya membuat penelitian mampu menjelaskan fenomena secara deskriptif yang tidak memiliki kekuatan generalisasi. Keterbatasan lainnya ialah penelitian ini menggunakan analisis konten yang mengasumsikan apa yang dilaporkan benar-benar dapat dilaksanakan perusahaan. Keabsahan informasi menjadi suatu hal yang tidak dikontrol dalam penelitian ini.

Aris, N. A., Madah Marzuki, M., Othman, R., Abdul Rahman, S., \& Hj Ismail, N. (2018). Designing indicators for cooperative sustainability: The Malaysian perspective. Social Responsibility Journal, 14(1), 226-248. https://doi.org/10.1108/SRJ01-2017-0015 
Atan, R., Alam, Md. M., Said, J., \& Zamri, M. (2018). The impacts of environmental, social, and governance factors on firm performance: Panel study of Malaysian companies. Management of Environmental Quality: An International Journal, 29(2), 182-194.

https://doi.org/10.1108/MEQ -03-2017-0033.

Bhatia, A., \& Tuli, S. (2018).

Sustainability reporting: an empirical evaluation of emerging and developed economies. Journal of Global Responsibility, 9(2), 207-234. https:// doi.org/10.1108/JGR-012018-0003

Buallay, A. (2019). Is sustainability reporting (ESG) associated with performance? Evidence from the European banking sector. Management of Environmental Quality: An International Journal, 30(1), 98-115.

https://doi.org/10.1108/MEQ -12-2017-0149

Caesaria, A. F., \& Basuki, B. (2017). The study of sustainability report disclosure aspects and their impact on the companies' performance. SHS Web of Conferences, 34, 08001.

https://doi.org/10.1051/shsco $\mathrm{nf} / 20173408001$

Cantele, S., Tsalis, T., \& Nikolaou, I. (2018). A New Framework for Assessing the Sustainability Reporting
Disclosure of Water Utilities. Sustainability, 10(2), 433. https://doi.org/10.3390/su10 020433

Ching, H. Y., \& Gerab, F. (2016). Sustainability reports in Brazil through the lens of signaling, legitimacy and stakeholder theories. Social Responsibility Journal, 13(1), 95-110. https://doi.org//10.1108/SRJ10-2015-0147

Colaço, R., \& Simão, J. (2018).

Disclosure of corporate social responsibility in the forestry sector of the Congo Basin. Forest Policy and Economics, 92, 136-147. https://doi.org/10.1016/j.forp ol.2018.04.012

Creswell, J. W. (2013). Qualitative, Quantitative, and Mixed Methods Approaches (4th ed.). United States: SAGE Publications.

Cuesta, M. de la, \& Valor, C. (2013). Evaluation of the environmental, social and governance information disclosed by Spanish listed companies. Social Responsibility Journal, 9(2), 220-240. https://doi.org/10.1108/SRJ08-2011-0065 
Elkington, J. (1998). Accounting

For The Triple Bottom

Line. Measuring Business

Excellence, 22(3), 18-22.

Farraswan, M. F., Zulkarnain, M., \& Fajri, M. N. (2016). Disclosure level of sustainability report: study of indonesian stock exchange listed companies. 2(7), 5.

Freeman, R. E. (1984). Strategic

Management:

A

Stakeholder Approach.

Boston: Pitman.

Global Reporting Initiative. (2013a). An introduction to G4. Global Reporting Initiative.

Global Reporting Initiative. (2013b). Pedoman Pelaporan Keberlanjutan-Panduan Penerapan. Global Reporting Initiative.

Global Reporting Initiative. (2013c). Pedoman PElaporan

Keberlanjutan-Prinsip-

Prinsip Pelaporan dan Pengungkapan Standar. Global Reporting Initiative.

Guthrie, J., \& Parker, L. D. (1989). Corporate Social Reporting: A Rebuttal of Legitimacy Theory. Accounting and Business Research, 19(76), 343-352.

https://doi.org/10.1080/0001 4788.1989.9728863

INTOSAI (2013). Sustainability Reporting: Concepts, Frameworks and the Role of Supreme Audit Institutions. Retrieved from http://www.environmentalauditing.org

Jitmaneeroj, B. (2016). Reform priorities for corporate sustainability:

Environmental, social, governance, or economic performance? Management Decision, 54(6), 1497-1521. https://doi.org/10.1108/MD11-2015-0505

Jogiyanto. (2007). Metodologi

Penelitian Bisnis: Salah Kaprah dan PengalamanPengalaman. Yogyakarta: BPFE.

Khan, H., Azizul Islam, M., Kayeser Fatima, J., \& Ahmed, K. (2011). Corporate sustainability reporting of major commercial banks in line with GRI: Bangladesh evidence. Social Responsibility Journal, 7(3), 347-362. https://doi.org/10.1108/1747 1111111154509

Lähtinen, K., \& Myllyviita, T.<smiles>[134Os]</smiles>
Cultural sustainability in reference to the global reporting initiative (GRI) guidelines: Case forest bioenergy production in North Karelia, Finland. Journal of Cultural Heritage Management and Sustainable Development, 5(3), 290-318. https://doi.org/10.1108/JCH MSD-06-2013-0025 
Murphy, D., \& McGrath, D. (2013). ESG reporting - class actions, deterrence, and avoidance. Sustainability Accounting, Management and Policy Journal, 4(2), 216-235.

https://doi.org/10.1108/SAM PJ-Apr-2012-0016

Ong, S. H. (2016). Measuring the quality and identifying influencing factors of sustainability reporting: Evidence from the resources industry in Australia. Edith Cowan University, Perth.

Rietz, S. D. (2014). When accounts become information: A study of investors' ESG analysis practice. Scandinavian Journal of Management, 30(4), 395-408. https://doi.org/10.1016/j.sca man.2014.09.002

Sekaran, U., \& Bougie, R. (2016). Research Methods For Business: A Skill Building Approach (7th ed.). United States: Wiley.

Sila, I., \& Cek, K. (2017). The Impact of Environmental, Social and Governance Dimensions of Corporate Social Responsibility on Economic Performance: Australian Evidence. Procedia Computer Science, 120, 797-804. https://doi.org/10.1016/j.pro. 2017.11.310

Truant, E., Corazza, L., \& Scagnelli,
S. (2017). Sustainability and Risk Disclosure: An Exploratory Study on Sustainability Reports. Sustainability, 9(4), 636. https://doi.org/10.3390/su90 40636

Tsalis, T. A., Stylianou, M. S., \& Nikolaou, I. E. (2018). Evaluating the quality of corporate social responsibility reports: The case of occupational health and safety disclosures. Safety Science, 109, 313-323. https://doi.org/10.1016/j.ssci. 2018.06.015

Velte, P. (2017). Does ESG performance have an impact on financial performance? Evidence from Germany. Journal of Global Responsibility, 8(2), 169178. https://doi.org/10.1108/JGR11-2016-0029 